\title{
Review Article \\ Preemptive Circular Defence of Immature Insects: Definition and Occurrences of Cycloalexy Revisited
}

\author{
Guillaume J. Dury, ${ }^{1,2}$ Jacqueline C. Bede, ${ }^{1}$ and Donald M. Windsor ${ }^{2}$ \\ ${ }^{1}$ Department of Plant Science, McGill University, 21111 Lakeshore Road, Sainte-Anne-de-Bellevue, QC, Canada H9X 3 V9 \\ ${ }^{2}$ Smithsonian Tropical Research Institute, Apartado 0843-03092, Balboa, Ancón, Panama City, Panama \\ Correspondence should be addressed to Guillaume J. Dury; guillaume.dury@mail.mcgill.ca
}

Received 6 December 2013; Accepted 13 February 2014; Published 24 March 2014

Academic Editor: Jacques Hubert Charles Delabie

Copyright (c) 2014 Guillaume J. Dury et al. This is an open access article distributed under the Creative Commons Attribution License, which permits unrestricted use, distribution, and reproduction in any medium, provided the original work is properly cited.

Cycloalexy was coined by Vasconcellos-Neto and Jolivet in 1988 and further defined by Jolivet and collaborators in 1990 in reference to a specific type of circular defence. The term has been applied to numerous organisms, including adult insects, nymphs, and even vertebrates, but has lost precision with the accumulation of anecdotal reports not addressing key elements of the behaviour as first defined. We review the literature and propose three criteria that are sufficient and necessary to define the behaviour: (1) individuals form a circle; (2) defensive attributes of the individuals are positioned on the periphery of the circle, and as a result, the periphery of the circle uniformly contains either heads or abdomens; (3) animals preemptively adopt the circle as a resting formation, meaning it is not necessary to observe predation. When these considerations are taken into account, cycloalexy appears less common in nature than the literature suggests. We argue that unequivocal cases of cycloalexy have been found only in sawflies (Tenthredinoidea: Pergidae, Argidae), leaf beetles (Chrysolemidae: Galerucinae, Cassidinae, Chrysomelinae, Criocerinae), weevils (Curculionidae: Phelypera distigma), and midges (Diptera: Ceratopogonidae, Forcipomyia). Reports of cycloalexy in caterpillars (Saturniidae: Hemileucinae: Lonomia, Papilionidae) require further documentation. We report one new case of cycloalexy in thrips (Thysanoptera) and question reports of cycloalexic behaviour in other taxa.

\section{Introduction}

Some animals show a remarkable behaviour: they group in a tight circle for defence [1]. This behaviour is reminiscent of Carl von Clausewitz's 1812 Principles of War: "In strategy (...) the side that is surrounded by the enemy is better off than the side which surrounds its opponent, especially with equal or even weaker forces" [2]. Many animal species employ this strategy. For example, among vertebrates, muskoxen (Ovibos moschatus, Blainville, 1816) form a circle enclosing the young calves when attacked by wolves, their principal natural predators $[3,4]$. Their circular formation protects the most vulnerable body parts while the extremity that is best defended or involved in attack is at the periphery. Vasconcellos-Neto and Jolivet [5] coined the term "cycloalexy $($ kuklos $=$ circle, alexo $=$ defend $)$ " to describe a particular behaviour of gregarious insect larvae. They defined their new term as "the attitude adopted at rest by some insect larvae, both diurnal and nocturnal, in a tight circle where either the heads or ends of the abdomen are juxtaposed at the periphery, with the remaining larvae at the center of the circle. Coordinated movements such as the adoption of threatening attitudes, regurgitation, and biting, are used to repel predators or parasitoids." [1]. Several elements of the original definition distinguish cycloalexy from other circular formations occurring in nature.

However, as new examples of the behaviour have been proposed in the literature without addressing key aspects of the original definition, the distinctions between cycloalexic behaviour and other circular formations have become imprecise and weakened the concept of cycloalexy. Here, we will review reported examples of cycloalexy and question whether they meet the criteria of a revised definition or are alternative forms of aggregation. Our revised definition 
strives to adhere to the key aspects of cycloalexy as originally defined, while removing arbitrary and unnecessary criteria. This way, cycloalexy can be recognized as an evolutionarily convergent behaviour rather than several superficially similar behaviours.

1.1. Redefining Cycloalexy. The defensive nature of cycloalexy is paramount as it is found in the etymology of the term: "to defend" [11]. However, this key aspect of the behaviour can be problematic since cycloalexy has often been invoked upon fragmentary observations of groups rather than controlled ecological studies. Nevertheless, until species can be more thoroughly studied, we suggest that three criteria are sufficient to distinguish cycloalexy from other behaviours.

Criterion 1: Individuals Are Arranged in a Circle. The original definition specified "in a tight circle" [1], but we argue that tightness is subjective and should be removed from the definition.

Criterion 2: The Extremity Bearing Defensive Attribute Is Positioned Outwards. In the original definition, the periphery of the circle is uniform: "either the heads or ends of the abdomen are juxtaposed at the periphery" [1], sometimes with individuals at the centre with neither head nor abdomen reaching the periphery. This means that peripheral individuals in a given group face outwards or inwards, but not both. We argue that, in this statement, it was implicit that the best defended extremity is at the periphery since it is unlikely that individuals with their vulnerable side out could ever be at an advantage. Uniformity of the circle in this respect, then, becomes a corollary of our second criterion.

Criterion 3: The Circle Is Adopted as a Resting Formation. Following the original definition, we limit cycloalexy to cases when individuals are in resting or quiescent, nonfeeding periods. This makes cycloalexy a preemptive behaviour.

These criteria allow for the initial identification of cycloalexy by rapid, visual assessment. If later studies disprove defensiveness, then the behaviour studied is not cycloalexy. Additionally, although not specified in the original definition, we suggest adding the distinction that the behaviour is for the defence of the individuals themselves and others within the group, as opposed to the defence of a resource or nest. We also suggest removing the criterion that "Coordinated movements such as the adoption of threatening attitudes, regurgitation, and biting, are used to repel predators or parasitoids" [1], for several reasons. Cycloalexy is notably preemptive, taken regardless of the immediate presence of a threat; in some species, immature animals have passive defences made more efficient by a circular formation; and the second criterion of our amended definition already includes defence, either passive or active. Finally, although the original definition was limited to insect larvae, in this paper, we review all reports of cycloalexy and suggest removing the limitation altogether.

\section{Results}

See Table 1.

\section{Discussion}

3.1. Strict Cycloalexy. Among the records in the literature, some species demonstrate behaviour that precisely fit the revised definition and our three essential criteria of cycloalexy (Table 1). This is the case of Coelomera spp. (Coleoptera: Chrysomelidae: Galerucinae) and spitfire grubs Perga dorsalis Leach, 1817 (Hymenoptera: Tenthredinoidea: Pergidae) [1].

Approximately 35 species of genus Coelomera are cycloalexic and feed on Cecropia (Urticaceae). Most Cecropia plants are myrmecophytes protected by mutualistic Azteca ants (Formicidae: Dolichoderinae). The gregarious leaf beetle larvae feed during the day and rest at night, in a tight circular cluster with heads inside and abdomens at the periphery $[7,8]$. Their rear end is protected by a supra-anal shield and, when threatened, these larvae excrete a nauseating fluid from the anus. Therefore, the better protected part of the insect, the posterior, is facing outwards in the circle, with the more vulnerable head inside $[7,8]$. Thus, by orienting the same way, individual larvae protect themselves and other members of the group (Figures 1 and 2).

Spitfire grubs Perga dorsalis feed on Eucalyptus during the night and rest during the day in a circular formation [47]. The larvae rest with their heads at the periphery of the circle, with some larvae in the middle of the aggregation. When threatened, the larvae rear their heads and abdomens and regurgitate oils sequestered from their host Eucalyptus [47]. The oils are an effective deterrent of potential predators, including ants, birds, and mice [49]. The heads are the better protected part of the insects and, again, form the periphery of the circle.

\subsection{Examples of Cycloalexy That Do Not Agree with the Revised Definition}

3.2.1. The Oxymoron of Noncircular Cycloalexy. Gregarious caterpillars of genus Arsenura (Saturniidae: Arsenurinae) are reported to "show a kind of cycloalexy when resting on tree trunks during the day" [1]. The caterpillars align sideby-side or head-to-abdomen or both, in an elongated oval cluster [11]. The posture of these caterpillars with their heads, sides, and abdomens at the periphery in a linear mass rather than a circle does not meet the first criterion of the revised definition of cycloalexy. The circle formation with the best defended extremity outwards is an important characteristic of cycloalexic behaviour. Arsenura are gregarious and rest in a tightly aggregated mass, but they are not cycloalexic. Santiago-Blay et al. [11] suggest that, on a tree trunk, "the available background surface makes the shape of the larval aggregation distorted." However, on the scale of a caterpillar, and depending on the diameter of the tree, a tree trunk can be quite large and nearly flat. In addition, probable cycloalexy on tree trunks has been observed in Lonomia sp. (Figure 3(b)). We suggest the caterpillar aggregations described by Santiago-Blay et al. [11] are less circular and compact not because of the shape of tree trunks but because Arsenura caterpillars' resting positions are not cycloalexic. 
TABLE 1: Reported cases of cycloalexy and how they fit within the revised definition.

\begin{tabular}{|c|c|c|c|c|c|c|}
\hline \multirow[b]{2}{*}{ Organism } & \multicolumn{3}{|c|}{ Criteria } & \multirow[b]{2}{*}{$\begin{array}{l}\text { Aggregation is } \\
\text { defensive (not } \\
\text { for nest } \\
\text { protection) }\end{array}$} & \multirow[b]{2}{*}{$\begin{array}{l}\text { Is the } \\
\text { behaviour } \\
\text { cycloalexy? }\end{array}$} & \multirow[b]{2}{*}{ Reference } \\
\hline & $\begin{array}{l}1 \\
\text { Circular } \\
\text { formation }\end{array}$ & $\begin{array}{l}2 \\
\text { Best defended } \\
\text { extremity at the } \\
\text { periphery }\end{array}$ & $\begin{array}{l}\quad 3 \\
\text { Default rest } \\
\text { position }\end{array}$ & & & \\
\hline \multicolumn{7}{|l|}{ Coleoptera: Chrysomelidae: } \\
\hline Galerucinae & & & & & & \\
\hline $\begin{array}{l}\text { Coelomera spp.; for example, } \\
\text { C. ruficornis Baly, } 1865 \text {; } \\
\text { C. helenae Jolivet, 1987; } \\
\text { C. raquia Bechyně, 1956; and so forth }\end{array}$ & Yes & Yes, abdomens & Yes & Yes & Yes & {$[1,5-8]$} \\
\hline Dircema spp. & $\begin{array}{c}\text { Not } \\
\text { observed }\end{array}$ & Not observed & $\begin{array}{c}\text { Not } \\
\text { observed }\end{array}$ & Not observed & $\begin{array}{c}\text { None } \\
\text { observed }\end{array}$ & {$[6,7]$} \\
\hline \multicolumn{7}{|l|}{ Coleoptera: Chrysomelidae: Criocerinae } \\
\hline $\begin{array}{l}\text { Lema sp.; } \\
\text { Lema apicalis Lacordaire, } 1845 \text { and } \\
\text { L. reticulosa Clark, } 1866\end{array}$ & Yes & Yes, heads & Yes & Yes & Yes & $\begin{array}{l}\text { (Figure } 1(\mathrm{a})) \\
\quad[9,10]\end{array}$ \\
\hline $\begin{array}{l}\text { Lilioceris nigropectoralis (Pic, 1928), } \\
\text { L. formosana Heinze, } 1943\end{array}$ & Yes & Yes, heads & Yes & Yes & Yes & $\begin{array}{c}\text { (Figure } 1(\mathrm{~b})) \\
{[11]}\end{array}$ \\
\hline \multicolumn{7}{|l|}{$\begin{array}{l}\text { Coleoptera: Chrysomelidae: } \\
\text { Chrysomelinae }\end{array}$} \\
\hline Agrosteomela chinensis (Weise, 1922) & $\begin{array}{c}\text { Not } \\
\text { observed }\end{array}$ & Not observed & $\begin{array}{c}\text { Not } \\
\text { observed }\end{array}$ & Not observed & $\begin{array}{c}\text { None } \\
\text { observed }\end{array}$ & [11-13] \\
\hline Chrysophtharta obovata (Chapuis, 1877) & Yes & Yes, abdomens & Yes & Probably & Yes & {$[11,14]$} \\
\hline $\begin{array}{l}\text { Doryphora paykulli (Stål, 1859), D. } \\
\text { reticulata Fabricius, } 1787\end{array}$ & Yes & $\begin{array}{l}\text { Unclear, } \\
\text { abdomens }\end{array}$ & Yes & Yes & $\mathrm{No}^{*}$ & {$[15]$} \\
\hline Eugonycha melanostoma (Stål, 1859) & Yes & $\begin{array}{l}\text { Unclear, } \\
\text { abdomens }\end{array}$ & $\begin{array}{l}\text { Not } \\
\text { reported }\end{array}$ & Not reported & Tentatively & {$[7,11]$} \\
\hline Gonioctena sibirica Kimoto, 1994 & Roughly & $\begin{array}{l}\text { Unclear, mostly } \\
\text { abdomens }\end{array}$ & Mostly & Unclear & Unclear & {$[11,12,16]$} \\
\hline $\begin{array}{l}\text { Labidomera suturella Guérin-Méneville, } \\
1838\end{array}$ & $\begin{array}{c}\text { Not } \\
\text { observed }\end{array}$ & Not observed & $\begin{array}{c}\text { Not } \\
\text { observed }\end{array}$ & Not observed & $\begin{array}{c}\text { None } \\
\text { observed }\end{array}$ & {$[11,17-19]$} \\
\hline $\begin{array}{l}\text { Paropsis spp.; for example, } \\
P . \text { aegrota Boisduval, } 1835, \\
P . \text { maculata (Marsham, } 1908 \text { ), } \\
P . \text { atomaria Olivier, } 1807 \text { and } \\
P . \text { tasmanica Baly, } 1864\end{array}$ & Not circular & $\begin{array}{l}\text { No, mixed } \\
\text { extremities }\end{array}$ & No & Perhaps, unclear & No & $\begin{array}{l}{[7,11,14,20} \\
21]\end{array}$ \\
\hline Paropsisterna spp. & $\begin{array}{l}\text { Not } \\
\text { reported }\end{array}$ & Not reported & $\begin{array}{l}\text { Not } \\
\text { reported }\end{array}$ & Not reported & $\begin{array}{l}\text { Not enough } \\
\text { information }\end{array}$ & {$[11,12,14,20]$} \\
\hline $\begin{array}{l}\text { Plagiodera spp. for example, } \\
\text { P. versicolora (Laicharting, 1781) }\end{array}$ & Not circular & $\begin{array}{l}\text { No, mixed } \\
\text { extremities }\end{array}$ & No & No & No & {$[7,22-25]$} \\
\hline Phratora spp. & $\begin{array}{c}\text { Not } \\
\text { observed }\end{array}$ & Not observed & $\begin{array}{c}\text { Not } \\
\text { observed }\end{array}$ & Not observed & $\begin{array}{c}\text { None } \\
\text { observed }\end{array}$ & {$[7,11]$} \\
\hline Phyllocharis undulata (Linnaeus, 1763) & Roughly & $\begin{array}{l}\text { Unclear, mostly } \\
\text { abdomens }\end{array}$ & No & Not observed & No & {$[11,26]$} \\
\hline $\begin{array}{l}\text { Platyphora selva Daccordi, 1993, } \\
\text { P. microspina (Bechyně, 1954) }\end{array}$ & Yes & $\begin{array}{l}\text { Unclear, } \\
\text { abdomens }\end{array}$ & Yes & Yes & $\mathrm{No}^{*}$ & {$[15,27]$} \\
\hline $\begin{array}{l}\text { Platyphora conviva (Stål, 1858), } \\
\text { P. anastomozans (Perty, 1832), } \\
\text { P. nigronotata (Stål, 1857), } \\
\text { P. nitidissima (Stål, 1857) } \\
\text { P. fasciatomaculata (Stål, 1857), } \\
P . \text { vinula (Stål, 1858) }\end{array}$ & Yes & Yes, heads & Yes & Yes & Yes & {$[7,9,10,28]$} \\
\hline
\end{tabular}


TABle 1: Continued.

\begin{tabular}{|c|c|c|c|c|c|c|}
\hline \multirow[b]{3}{*}{ Organism } & \multicolumn{3}{|c|}{ Criteria } & \multirow{3}{*}{$\begin{array}{l}\text { Aggregation is } \\
\text { defensive (not } \\
\text { for nest } \\
\text { protection) }\end{array}$} & \multirow{3}{*}{$\begin{array}{l}\text { Is the } \\
\text { behaviour } \\
\text { cycloalexy? }\end{array}$} & \multirow[b]{3}{*}{ Reference } \\
\hline & 1 & & 3 & & & \\
\hline & $\begin{array}{l}\text { Circular } \\
\text { formation }\end{array}$ & $\begin{array}{l}\text { Best defended } \\
\text { extremity at the } \\
\text { periphery }\end{array}$ & $\begin{array}{l}\text { Default rest } \\
\text { position }\end{array}$ & & & \\
\hline $\begin{array}{l}\text { Proseicela vittata (Fabricius, 1781), } \\
\text { P. bicruciata Jacoby, 1880, } \\
\text { P. spectabilis (Baly, 1858) }\end{array}$ & Yes & $\begin{array}{l}\text { Unclear, } \\
\text { abdomens }\end{array}$ & Yes & Yes & $\mathrm{No}^{*}$ & $\begin{array}{c}\text { (Figure 5(a)) } \\
{[15]}\end{array}$ \\
\hline Proseicela crucigera (Sahlberg, 1823) & Yes & $\begin{array}{l}\text { Unclear, } \\
\text { abdomens }\end{array}$ & Yes & Yes & $\begin{array}{l}\text { Not enough } \\
\text { information }\end{array}$ & {$[7,9]$} \\
\hline Pterodunga mirabile Daccordi, 2000 & Yes & $\begin{array}{l}\text { Unclear, } \\
\text { abdomens }\end{array}$ & $\begin{array}{l}\text { Not } \\
\text { reported }\end{array}$ & Not reported & $\begin{array}{l}\text { Not enough } \\
\text { information }\end{array}$ & {$[11,12,19]$} \\
\hline \multicolumn{7}{|l|}{ Coleoptera: Chrysomelidae: Cassidinae } \\
\hline Acromis sparsa (Boheman, 1854) & Yes & Yes, abdomens & Yes & Yes & Yes* $^{*}$ & {$[7,11,29]$} \\
\hline $\begin{array}{l}\text { Aspidomorpha puncticosta Boheman, } \\
\text { 1854, } \\
\text { A. miliaris (Fabricius, 1775) }\end{array}$ & Yes & Yes, abdomens & Yes & Yes & Yes & {$[7,30-32]$} \\
\hline $\begin{array}{l}\text { Chelymorpha informis Boheman, } 1854 \text {, } \\
\text { C. alternans Boheman, } 1854 \text {, } \\
\text { C. cribraria (Fabricius, 1875) }\end{array}$ & Yes & Yes, abdomens & Yes & Yes & Yes & {$[7,8]$} \\
\hline Cistudinella foveolata (Champion, 1894) & Yes & Yes, abdomens & Yes & Probably & Yes & (Figure 2(a)) \\
\hline $\begin{array}{l}\text { Conchyloctenia punctata (Fabricius, } \\
\text { 1787) }\end{array}$ & Yes & Yes, abdomens & Yes & Yes & Yes & {$[7,30,33]$} \\
\hline Coptocycla dolosa Boheman, 1855 & Yes & Yes, abdomens & Yes & Probably & Yes & (Figure 4) \\
\hline $\begin{array}{l}\text { Eugenysa columbiana (Boheman, 1850), } \\
\text { E. coscaroni Viana, } 1968\end{array}$ & Yes & Yes, abdomens & Yes & Yes & Yes* $^{*}$ & $\begin{array}{c}\text { (Figure 2(b)) } \\
{[34,35]}\end{array}$ \\
\hline Paraselenis flava (Linnaeus, 1758) & Yes & Yes, abdomens & Yes & Yes & Yes $^{*}$ & {$[8]$} \\
\hline Nuzonia sp. & Yes & Yes, abdomens & Yes & Yes & Yes & (Figure 2(c)) \\
\hline $\begin{array}{l}\text { Ogdoecosta biannularis (Boheman, } \\
\text { 1854) }\end{array}$ & Yes & Yes, abdomens & Yes & Yes & Yes & {$[7,11,36]$} \\
\hline $\begin{array}{l}\text { Omaspides tricolorata (Boheman, 1854), } \\
\text { O. pallidipennis (Boheman, 1854), } \\
\text { O. sobrina (Boheman, 1854), } \\
\text { O. bistriata (Boheman, 1854) and } \\
\text { O. convexicollis Spaeth, } 1909\end{array}$ & Yes & Yes, abdomens & Yes & Yes & Yes $^{*}$ & $\begin{array}{l}\text { [7, 11, 32, 35, } \\
\text { 37-39] (D. } \\
\text { Windsor's } \\
\text { observations) }\end{array}$ \\
\hline Physonota alutacea Boheman, 1854 & Yes & Yes, abdomens & Yes & Probably & Yes & (Figure $2(\mathrm{~d})$ ) \\
\hline Polychalma multicava (Latreille, 1821) & Yes & Yes, abdomens & Yes & Probably & Yes & (Figure 2(e)) \\
\hline $\begin{array}{l}\text { Stolas sp., } \\
\text { Stolas xanthospila (Champion, 1893) }\end{array}$ & Yes & Yes, abdomens & Yes & Probably & Yes & $\begin{array}{c}\text { (Figure 2(f)) } \\
{[7]}\end{array}$ \\
\hline $\begin{array}{l}\text { Coleoptera: Curculionidae: Hyperinae } \\
\text { Phelypera distigma (Boheman, 1842) }\end{array}$ & Yes & Yes, heads & Yes & Yes & Yes & {$[24,40,41]$} \\
\hline \multicolumn{7}{|l|}{$\begin{array}{l}\text { Diptera: Ceratopogonidae: } \\
\text { Forcipomyiinae }\end{array}$} \\
\hline Forcipomyia fuliginosa (Meigen, 1818) & Yes & Yes, abdomens & Yes & Probably & Yes & {$[1,11,42-44]$} \\
\hline \multicolumn{7}{|l|}{ Hemiptera } \\
\hline Not specified & $\begin{array}{l}\text { Not } \\
\text { reported }\end{array}$ & Not reported & $\begin{array}{l}\text { Not } \\
\text { reported }\end{array}$ & Not reported & $\begin{array}{l}\text { Not enough } \\
\text { information }\end{array}$ & {$[11,12]$} \\
\hline $\begin{array}{l}\text { Ceroplastes sp. (Coccidea), } \\
\text { Potnia sp. (Membracidae), } \\
\text { Nephesa rosea (Spinola, 1839) (Flatidae), } \\
\text { Derbe sp. (Derbidae) }\end{array}$ & $\begin{array}{l}\text { Roughly to } \\
\text { not circular }\end{array}$ & $\begin{array}{l}\text { No, mixed } \\
\text { extremities }\end{array}$ & No & Unclear & No & {$[11]$} \\
\hline $\begin{array}{l}\text { Antiteuchus tripterus (Fabricius, 1787) } \\
\text { (Pentatomidae) }\end{array}$ & Yes & $\begin{array}{l}\text { Unclear, } \\
\text { abdomens }\end{array}$ & No & No & No & {$[45]$} \\
\hline $\begin{array}{l}\text { Parastrachiajaponensis (Scott, 1880) } \\
\text { (Parastrachiidae) }\end{array}$ & Yes & $\begin{array}{l}\text { Unclear, } \\
\text { abdomens }\end{array}$ & No & No & No & {$[46]$} \\
\hline
\end{tabular}


TABLE 1: Continued.

\begin{tabular}{|c|c|c|c|c|c|c|}
\hline \multirow[b]{2}{*}{ Organism } & \multicolumn{3}{|c|}{ Criteria } & \multirow[b]{2}{*}{$\begin{array}{l}\text { Aggregation is } \\
\text { defensive (not } \\
\text { for nest } \\
\text { protection) }\end{array}$} & \multirow[b]{2}{*}{$\begin{array}{l}\text { Is the } \\
\text { behaviour } \\
\text { cycloalexy? }\end{array}$} & \multirow[b]{2}{*}{ Reference } \\
\hline & $\begin{array}{l}1 \\
\text { Circular } \\
\text { formation }\end{array}$ & $\begin{array}{l}2 \\
\text { Best defended } \\
\text { extremity at the } \\
\text { periphery }\end{array}$ & $\begin{array}{l}3 \\
\text { Default rest } \\
\text { position }\end{array}$ & & & \\
\hline \multicolumn{7}{|l|}{ Hymenoptera: Tenthredinoidea } \\
\hline Bergiana sp. (Cimbicidae) & Yes & Not reported & $\begin{array}{l}\text { Not } \\
\text { reported }\end{array}$ & Not reported & $\begin{array}{l}\text { Not enough } \\
\text { information }\end{array}$ & {$[1]$} \\
\hline $\begin{array}{l}\text { Perga dorsalis Leach, 1817, P. affinis } \\
\text { Kirby, } 1882 \text { (Pergidae) }\end{array}$ & Yes & Yes, heads & Yes & Yes & Yes & $\begin{array}{c}\text { (Figure } 3(\mathrm{a}) \text { ) } \\
{[7,11,12,47} \\
48]\end{array}$ \\
\hline $\begin{array}{l}\text { Pseudoperga guerini (Westwood, 1880) } \\
\text { (Pergidae) }\end{array}$ & Yes & Yes, heads & Yes & Yes & Yes & {$[49]$} \\
\hline Themos olfersii (Klug, 1834) (Argidae) & Yes & Yes, heads & Yes & Yes & Yes & {$[1,50]$} \\
\hline Dielocerus diasi Smith, 1975 (Argidae) & $\begin{array}{l}\text { Not } \\
\text { reported }\end{array}$ & Not reported & $\begin{array}{l}\text { Not } \\
\text { reported }\end{array}$ & Unclear & $\begin{array}{l}\text { Not enough } \\
\text { information }\end{array}$ & {$[1,50]$} \\
\hline \multicolumn{7}{|l|}{ Hymenoptera: other superfamilies } \\
\hline Trigona sp. (Apidae: Meliponinae) & Yes & Yes, heads & No & No & No & {$[1,7,11,51]$} \\
\hline $\begin{array}{l}\text { Adult Hymenoptera, } \\
\text { bees (Apidae), } \\
\text { wasps (Vespidae), } \\
\text { Conomyrma spp. and numerous other } \\
\text { ants (Formicidae) }\end{array}$ & $\begin{array}{l}\text { Some } \\
\text { circular, } \\
\text { some not }\end{array}$ & Yes, usually heads & No & No & No & {$[11]$} \\
\hline Apoica sp. (Vespidae: Polistinae) & Yes & Yes, heads & Yes & No & No & {$[52-54]$} \\
\hline $\begin{array}{l}\text { "Parasitic Hymenoptera larvae and } \\
\text { pupae [on] their host" }\end{array}$ & Yes & $\begin{array}{l}\text { Unclear, } \\
\text { abdomens }\end{array}$ & No & No & No & {$[11]$} \\
\hline $\begin{array}{l}\text { Lepidoptera: Papilionidae: Papilioninae } \\
\text { Papilio laglaizei Depuiset, } 1877\end{array}$ & Yes & Unclear, heads & Yes & Not reported & Tentatively & {$[24,55]$} \\
\hline \multicolumn{7}{|l|}{ Lepidoptera: Saturniidae } \\
\hline Hylesia spp. (Hemileucinae) & Unclear & Not reported & Yes & Probably & $\begin{array}{l}\text { Not enough } \\
\text { information }\end{array}$ & [7] \\
\hline Lonomia spp. (Hemileucinae) & Yes & Probably, heads & Yes & Probably & Probably & $\begin{array}{c}\text { (Figure 3(b)) } \\
{[11,56,57]}\end{array}$ \\
\hline Arsenura spp. (Arsenurinae) & Not circular & $\begin{array}{l}\text { No, mixed } \\
\text { extremities }\end{array}$ & Yes & Probably not & No & {$[1,11]$.} \\
\hline $\begin{array}{l}\text { Lepidoptera: other families } \\
\text { Noctuidae and } \\
\text { Sphingidae }\end{array}$ & Not circular & $\begin{array}{l}\text { No, mixed } \\
\text { extremities }\end{array}$ & $\begin{array}{l}\text { Not } \\
\text { reported }\end{array}$ & Probably not & No & {$[11]$} \\
\hline $\begin{array}{l}\text { Neuroptera: Ascalaphidae } \\
\text { Ascaloptynx furciger (McLachlan, 1891) }\end{array}$ & $\begin{array}{l}\text { Yes, around } \\
\text { twig }\end{array}$ & $\begin{array}{l}\text { No, mixed } \\
\text { extremities }\end{array}$ & No & Yes & No & {$[1,11,12,58]$} \\
\hline $\begin{array}{l}\text { Thysanoptera: Phlaeothripidae } \\
\text { Anactinothrips nigricornis Hood, } 1936 \\
\text { and } \\
\text { A. gustaviae Mound \& Palmer, } 1983\end{array}$ & Yes & Yes, abdomens & Yes & Probably & Yes & $\begin{array}{c}\text { (Figure 5(b)) } \\
{[59]}\end{array}$ \\
\hline $\begin{array}{l}\text { Non-insect arthropods } \\
\text { Phronima sedentaria (Forskål, 1775) } \\
\text { (Crustacea: Amphipoda: Hyperiidea) }\end{array}$ & Yes & Unclear, heads? & Yes & No & $\mathrm{No}^{*}$ & {$[24,60,61]$} \\
\hline $\begin{array}{l}\text { Platydesmidae, Unidentified sp. } \\
\text { (Myriapoda) }\end{array}$ & Yes & $\begin{array}{l}\text { Unclear, } \\
\text { abdomens }\end{array}$ & $\begin{array}{c}\text { Not } \\
\text { reported }\end{array}$ & Not reported & $\begin{array}{l}\text { Tentatively } \\
\text { analogous }\end{array}$ & {$[24,62]$} \\
\hline \multicolumn{7}{|l|}{ Vertebrates } \\
\hline $\begin{array}{l}\text { Some ungulates, for example, } \\
\text { Muskoxen Ovibos moschatus } \\
\text { (Zimmermann, 1780) }\end{array}$ & Yes & Yes, heads & No & Yes & No & {$[1,11,12]$} \\
\hline Antarctic penguins & Yes & Unclear, backs & Yes & No & No & {$[12,63]$} \\
\hline
\end{tabular}

\footnotetext{
${ }^{*}$ These taxa are maternally defended and pose a special challenge to the definitions of cycloalexy (see Section 3.2.5).
} 


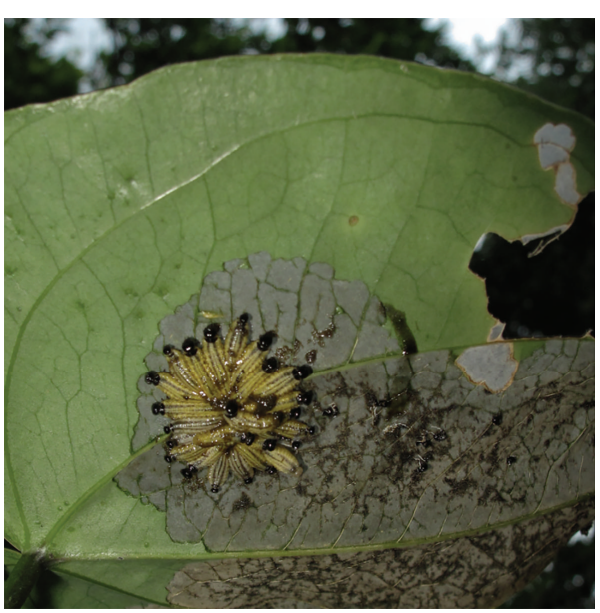

(a)

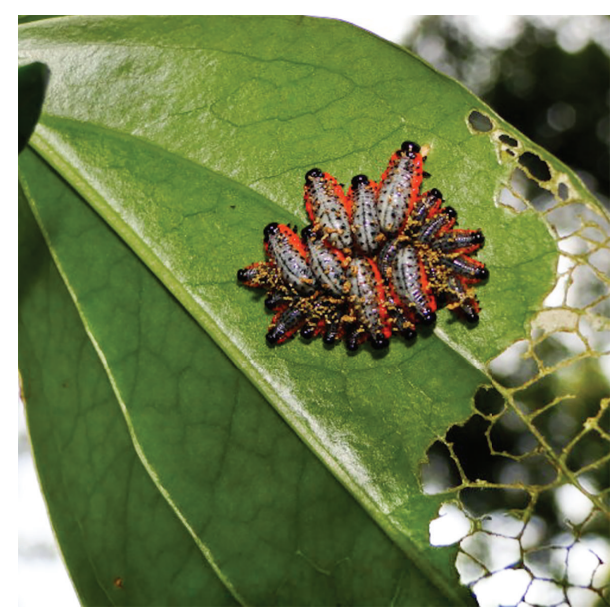

(b)

FIGURE 1: Cycloalexywith heads outwards in shining leaf beetle larvae (Criocerinae). (a) Larvae of Lema sp. at rest, photograph in Potrerillos del Guendà, Dept. Santa Cruz, Bolivia, ( ) D. Windsor. (b) Lilioceris nigropectoralis larvae in Taiwan. Seven larvae are distinctly larger and appear to be from a different cohort than the other twelve. Photograph taken in Yangmingshan National Park on 2 August 2011, by 劉達偉 (Liu Dá Wěi), and licensed under the Creative Commons 3.0 Taiwan (CC BY-NC 3.0 TW).

3.2.2. Mixed Head Orientations. Larvae of the owlfly Ascaloptynx furciger (McLachlan, 1891) (Neuroptera: Ascalaphidae) are gregarious. After eclosion and their first meal of abortive eggs, they settle head-downwards on and around the twig on which they were laid [58]. Jolivet et al. [1] deem the behaviour of A. furciger is "not strictly cycloalexy but related to it" since the owlfly larvae all point in the same downward direction: this does not meet the second criterion of the revised definition. We agree with Jolivet and Verma [12] that cycloalexy exists around twigs and is not restricted to flat surfaces. However, even on small branches, cycloalexic larvae collectively orient their heads either outwards or inwards, but not both. This is true for larvae of Perga sp. (Hymenoptera: Tenthredinoidea: Pergidae) (Figure 3(a)), Omaspides tricolorata (Boheman, 1854) [39], and this arrangement is retained in the pupae of Omaspides pallidipennis (Boheman, 1854) (Chrysomelidae: Cassidinae) [37]. For owlfly larvae, heads form the periphery at the bottom of the aggregation and abdomens are at the periphery on top, but unlike Cassidinae or Coelomera larvae, their abdomens are more vulnerable. It is more accurate to describe the behaviour as unidirectional defence rather than circular defence; larvae are only protected from predators walking up to the group. Secondly, larvae also feed while, in this position, making it a passive hunting formation and not only a resting position [58]. Because they do not meet the second and third criteria, we question reports of cycloalexy in Neuroptera $[7,11,12,64]$.

3.2.3. Nonresting Behaviours. As stated in the third criterion, cycloalexy is adopted preemptively by animals at rest. When immature insects are active and feeding, the circular formation is normally broken (Figure 4). Larvae of Plagiodera versicolora (Laicharting, 1781) and other Plagiodera species form a loose circle when feeding and at rest, with individual larvae not consistently facing outwards or inwards [22, pers. obs.]. Hence their formation is not an example of cycloalexy. Their formation is not only adopted at rest but also while feeding and is often influenced by the shape of the leaf, with multiple "feeding rings" on larger leaves [22]. Some authors [11] feel that cycloalexy facilitates feeding in P. versicolora as well as in sawflies. Larval aggregations can increase feeding efficiency through synchronized, coordinated, and spatially concentrated feeding [23-25].The size of $P$. versicolora groups does not influence survival of larvae, but does help with feeding [25]. Thus, available evidence suggests grouping in P. versicolora is related principally to the process of feeding rather than defence.

3.2.4. Nondefensive Behaviour. Cycloalexy is a defensive behaviour; it protects individuals from predation or parasitism. Yet, some reported behaviours are not defensive. Such is the case for huddling in Antarctic penguins, where the huddle is a resting behaviour, usually with heads inwards, but it is for heat conservation rather than defence [63]. For these reasons, we disagree with Jolivet and Verma [12] that penguins are cycloalexic.

To conclusively prove the defensive value of a behaviour, ecological studies are needed. Yet, for many species, the defensive value of cycloalexy has been inferred from anecdotal evidence or personal observations or has simply been presumed. For example, the defensive value of cycloalexy in Phelypera distigma larvae is supported by the following statement: "P. distigma larvae are not harvested by polistine wasps, ants, spiders, and other generalist predators that readily harvest caterpillars in dry forest habitats (D. H. Janzen, pers. obs.)" [65].

Rather than rejecting the many reports of cycloalexy on the basis of insufficient ecological studies, we propose that defensive nature of the aggregation can be accepted if the 


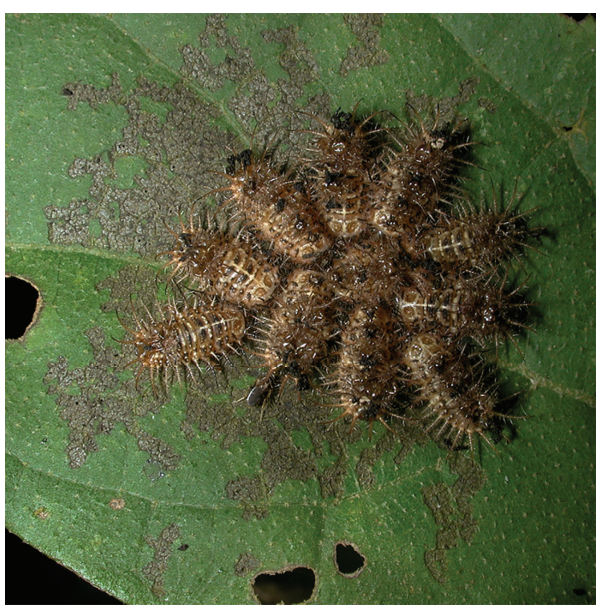

(a)

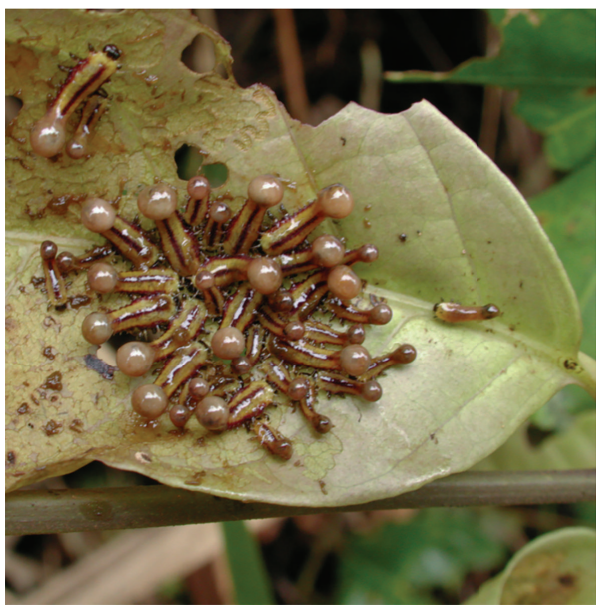

(c)

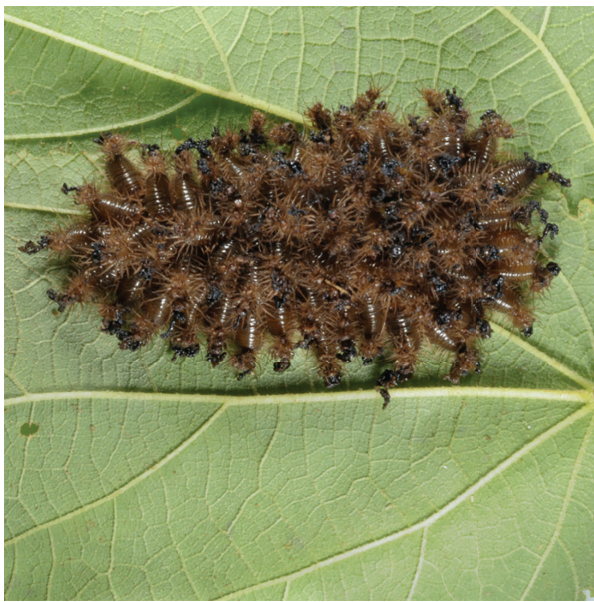

(e)

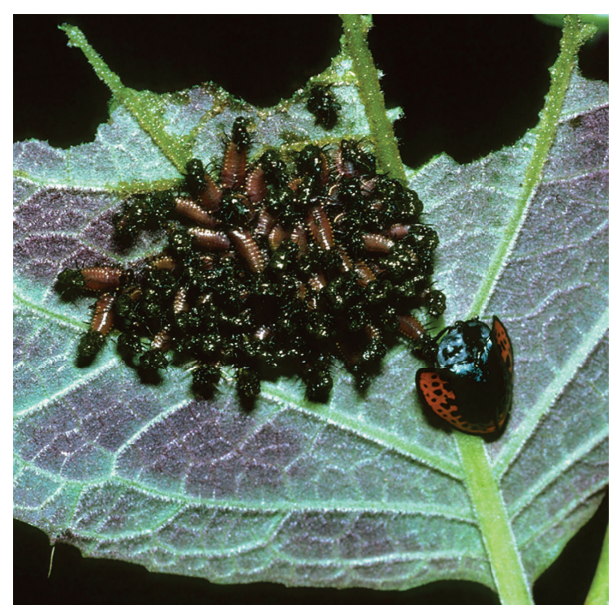

(b)

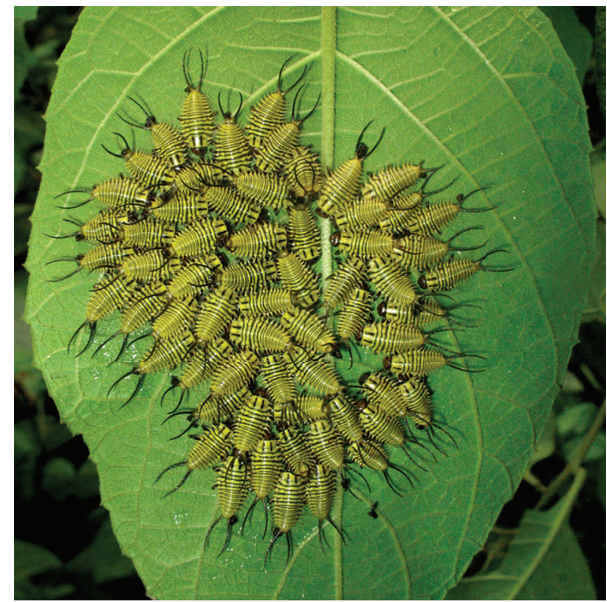

(d)

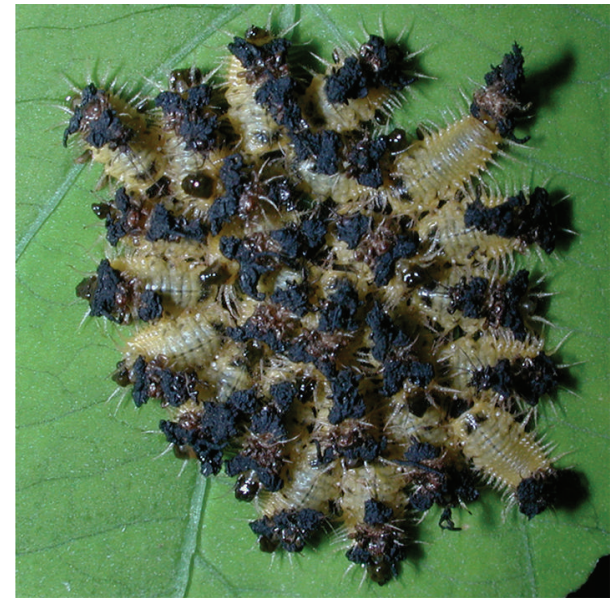

(f)

FIgure 2: Cycloalexy in tortoise beetle larvae. (a) Cistudinella foveolata (Ischyrosonychini) larvae on host Cordia alliodora (Ruiz \& Pav.) Oken. Gamboa, Colón Province, Panama; (b) Eugenysa coscaroni (Eugenysini) larvae and mother on host Mikania guaco Bonpl. (Asteraceae), Cerro Campana, Panama Province, Panama; (c) Nuzonia sp. on host Maripa nicaraguensis Hemsl., Chiriquí Grande, Bocas del Toro Province, Panama; (d) Physonota alutacea (Ischyrosonychini) larvae on host Cordia spinescens L., Gamboa, Colón Province, Panama; (e) Polychalma multicava (Goniocheniini) larvae on host Helicteres guazumaefolia Kunth. (Sterculiaceae), Gamboa, Colón Province, Panama; (f) Stolas xanthospila (Mesomphaliini) larvae on host Turbina corymbosa (L.) Raf. (Convolvulaceae), Cerro Campana, Panama Province, Panama; all photographs (c) D. Windsor. 


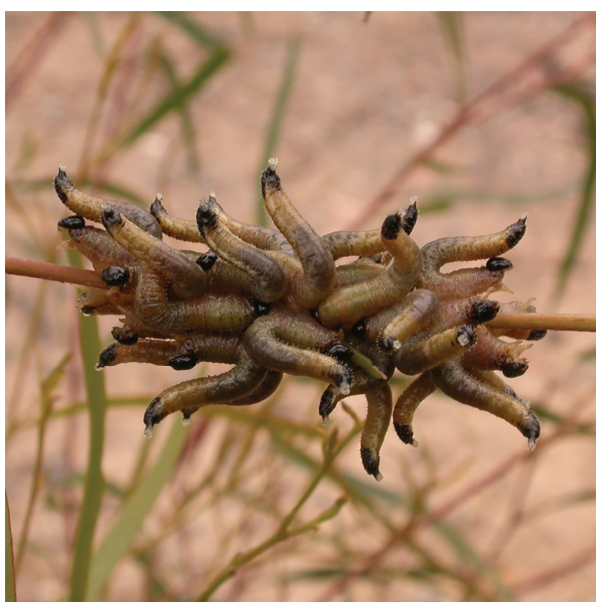

(a)

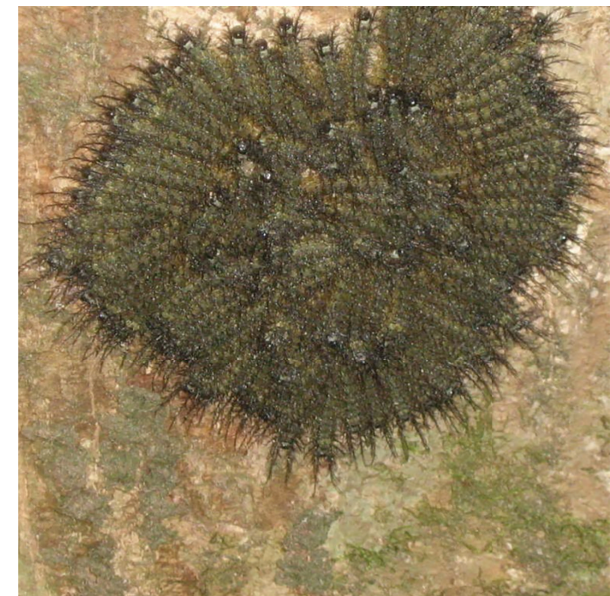

(b)

Figure 3: (a) Larvae of Perga sp. (Pergidae) rest aggregated in a cycloalexic formation. Even around a stem of their host plant, Eucalyptus sp., spitfire larvae rest with their heads outwards, Black Mountain, Canberra, ACT, Australia. Photograph by Donald Hobern on 24 May 2010 (CC BY 2.0). (b) Probable cycloalexy with heads pointing outwards in caterpillars of Lonomia sp. (Saturniidae: Hemileucinae) on tree trunk in Peru. Photograph taken near Pongo de Caynarachi, Lamas, San Martin, Peru, and reproduced with the author's permission $\odot$ Marc Díaz Rengifo (Universidad Nacional Federico Villarreal, Lima, Perú).

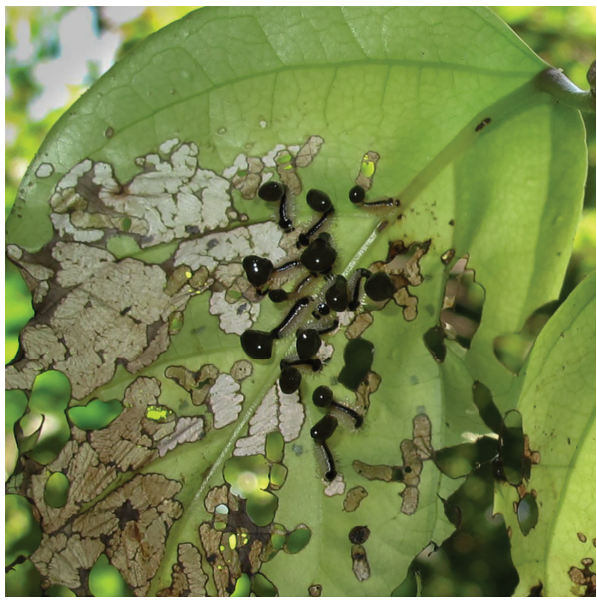

(a)

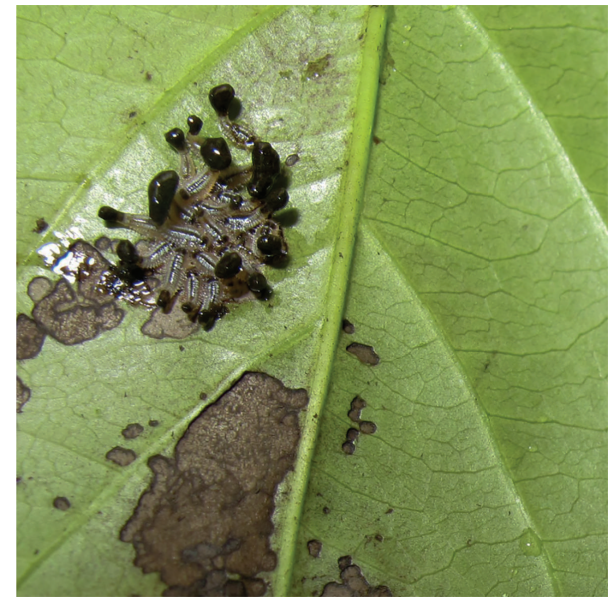

(b)

Figure 4: Coptocycla dolosa larvae, Potrerillos del Guendà, Dept. Santa Cruz, Bolivia. (a) when active, feeding, or moving; (b) at rest. (C) D. Windsor.

animals meet the other criteria: they are in a circle, taken preemptively with defensive armature uniform at the periphery. When ecological studies are conducted, if defensiveness is disproved, then the behaviour is another type of aggregation and not cycloalexy. This is the case for larval aggregations of Plagiodera versicolora: ecological studies were conducted and the survival of larvae is not significantly influenced by group size [25].

\subsubsection{Circular Formations That Do Not React to Threats.} The original definition of cycloalexy requires coordinated movements in response to threats [1]. We disagree with this requirement: in some larvae with passive protection, like the exuvial or exuvio-fecal shields of tortoise beetles, the circular groups do not always use coordinated movements when threatened by predators. For example, the larvae of Conchyloctenia punctata (Fabricius, 1787) (Cassidinae) are passively protected by their shields but do not have coordinated reactions to threats [30]. In our opinion, larvae of C. punctata meet the basic criteria of cycloalexy. Although coordinated group reactions to threats are an indication of the defensive nature of the group, we propose it is not an essential criterion for cycloalexy.

The removal of this criterion is also important for several taxa in which the larvae receive maternal care. Cassidinae larvae in maternal care species (e.g., species of genera Acromis, Omaspides, Paraselenis, and Eugenysa) generally have reduced fecal shields and do not always react defensively 
when threatened. Larval grouping in these species can be considered as increasing the efficiency of maternal guarding. In these cases, all criteria of the revised definition are met: larvae are in a circle, the best defended extremity is always at the periphery, and the circle is the default resting position. Thus, we consider larval aggregations in these maternal care species as further examples of cycloalexy (Table 1).

Similarly, larvae of several chrysomelines rest in tight circular groups with the heads pointing inwards: Doryphora paykulli (Stål, 1859), D. reticulata Fabricius, 1787, Platyphora microspina (Bechyně, 1954), P. selva Daccordi, 1993, Proseicela vittata (Fabricius, 1781), P. spectabilis (Baly, 1858), P. bicruciata Jacoby, 1880 and Pr. sp. nov. "Yasuni" [15]. All these species also have maternal care, and when disturbed, larvae do not have coordinated defensive reactions. Instead, the mother acts as the defensive element of the formation (Figure 5(a)) [15]. Is this behaviour still cycloalexy? In other words, should the defensive element obligatorily be found, at least in part, in the larvae? To this question, our answer is yes, through the second criterion. In Cassidinae larvae, the furca and shield are obvious defensive attributes positioned at the periphery. In Chrysomelinae, the best defended extremity is less obvious. Cycloalexic larvae of nonmaternal care Chrysomelinae face outwards. Their best defended extremity is the head and thorax, through regurgitation and biting [7]. We hypothesize that, in species with maternal care, the individuals face inwards not because the best defended extremity is the abdomen but because of herding by the mother, and thus, these species do not meet the second criterion of the revised definition. Ultimately, only ecological and evolutionary studies will provide a clear answer.

3.2.6. Adult Insects. We use Apoica as an example even though cycloalexy was not explicitly reported in this genus. During the day, these nocturnal wasps rest on the circular or nearly circular lower surface of their nests [52-54]. The wasps rest facing outwards, resulting in a circular formation that could loosely be termed cycloalexy. When disturbed, the formation breaks up as wasps fly off the nest. Even though this behaviour meets several criteria of the revised definition, we argue it is not cycloalexic because the shape of the nest or nest entrance explains the circular formation. In a similar fashion, stingless bees of genus Trigona (Apidae: Meliponinae) are not cycloalexic as suggested by Vasconcellos-Neto and Jolivet [7]. In this case, fully developed individuals are not even at rest: in most Meliponinae, the nest entrance is protected by bees positioned in or around the entrance tube and, at night, the entrance is closed [51]. The bees are not resting but are actively guarding and the ring formation is an artefact of the nest entrance shape.

These examples motivate limiting and specifying cycloalexy as a formation taken by individuals, whether immature or adult, for increased individual and mutual defences, thus excluding formations taken for defence of a nest, brood, or food stores. We argue that evolution of circular nests and resource guarding may have little to do with the evolution of cycloalexy.
3.2.7. Circular Defence in Vertebrates and the Selfish Herd. Several authors compare cycloalexy to the "circle-thewagons" formation employed by American pioneers to defend themselves against Native Americans $[1,11,12,24]$. In Jolivet et al. [1] and Jolivet and Verma [12], the authors discuss behaviours analogous to cycloalexy in vertebrates: muskoxen (Ovibos moschatus), eland (Taurotragus oryx (Pallas, 1766)), elk (Cervus canadensis (Erxleben, 1777)), and penguins. The authors do not provide citations for the behaviour in eland or elk and cite Wilson [4] for descriptions of this behaviour in muskoxen and penguins. Wilson [4] does not mention penguins in this manner but does mention similar behaviours in several terrestrial ungulates and killer whales (Orcinus orca (Linnaeus, 1758)) ([3, 66-69]; all page 45 in [4]). Wilson [4] describes elk grazing in a "windrow" formation but does not mention circular defence [70] and [4, page 45]. We agree that several vertebrates employ defensive circular formations analogous to cycloalexy. However, we would not broaden the definition to include these behaviours. Unlike invertebrates, mammals do not use circular defence when resting but take the formation when threatened. This does not meet the third criterion of the revised definition. In cycloalexic species, the circular formation is the main resting position. The circular defence of vertebrates is reactive, while cycloalexy in invertebrates is largely preemptive.

Hamilton used herding animals as an example of how individuals may form a group to lessen individual chances of falling to a predator without reducing overall predation [71]. Hamilton then cited the circular defence of muskoxen as a potential exception to the selfish herd theory but attributes it to selfish reasons: "they are probably connected on the one hand with the smallness of the risk taken and, on the other, with the closeness of the genetical relationship of the animals benefited" [71]. Because cycloalexy may lessen both overall and individual predation risk, it can also be considered selfish. Cycloalexy can be explained by animals exploiting the best defended extremity of nearby individuals. The preemptive aspect of arthropod cycloalexy also distinguishes it from muskoxen circular defence and Hamilton's selfish herds and may therefore provide interesting systems for study of group defence.

3.2.8. Cycloalexy in Immature Hemimetabolous Insects. We report cycloalexy in Anactinothrips nigricornis Hood, 1936 (Thysanoptera). We observed a group of 14 thrips, in their pupal instar, forming a tight circle with abdomens outwards on a leaf of the woody vine Maripa panamensis Hemsl. (Convolvulaceae) (Figure 5(b)). When disturbed, the threatened individuals and those beside them waved their abdomen. When disturbance continued, a brown liquid was exuded and formed a droplet at the end of the abdomen. The group was then further disturbed and the individuals dispersed. Approximately an hour later, the thrips had reassembled in a circular resting formation. In the lab, after the final moult, the adult thrips dispersed in the container in which they were kept. Similar observations were made in another species of the same genus: the thrips A. gustaviae, Mound and Palmer, 


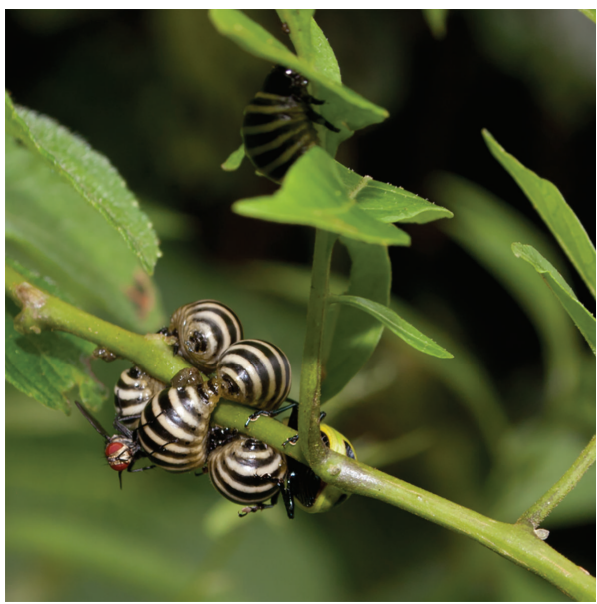

(a)

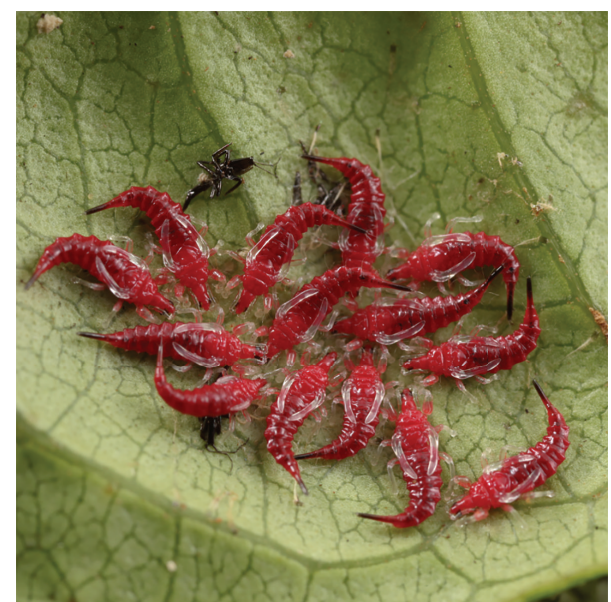

(b)

Figure 5: (a) Larvae of Proseicela spectabilis Baly (Chrysomelidae: Chrysomelinae) at rest encircling the stem of their host plant with tachinid fly at the bottom left of the cluster and the adult female beetle on the opposite side. Photograph taken in Reventador, Napo Province, Ecuador, () G. Dury. (b) Circular resting position in Panamanian thrips (Anactinothrips sp.) on Maripa panamensis Hemsl. (Convolvulaceae). Photograph taken 24 April 2013, on Cerro Campana, Panama. (C) G. Dury.

1983, rest in bivouacs and exude a defensive liquid from their abdomen when disturbed [59, 72].

The behaviour was observed in the mobile pupal stage rather than in the larvae. This goes against the original definition but meets all other criteria and assuming it is defensive, we consider the behaviour is cycloalexy. Thus, we propose to remove the taxonomical restriction of the original definition.

3.3. Common Traits of All Cycloalexic Species. When the revised definition of cycloalexy is strictly applied, a set of traits common to all species becomes apparent. Foremost, all cycloalexic species are insects with gregarious immature stages. Gregarious lifestyles have implications in terms of cooperative feeding and continued group cohesion through chemical, tactile, or acoustic communication [24].

To date, all cycloalexic species appear to use chemical defences of one sort or another. The cycloalexic larvae in genera Lema (Criocerinae) and Platyphora (Chrysomelinae) regurgitate when threatened [7, 9]. The larvae of Forcipomyia have paired setae on the head, thorax, and abdomen that exude hygroscopic substances that repel ants [44]. The chemical defences of gregarious Lonomia caterpillars are so potent that the resulting trauma caused by venom injected from their setae can be lethal to humans [73]. Most tortoise beetle larvae carry an exuvial or exuvio-fecal shield on the furca of their eighth abdominal segment which serves as a mechanical or chemical barrier against predators [74-76]. In all cases, the best protected extremity faces outwards.

Furthermore, all the species that exhibit cycloalexic behaviour are miniature grazers, and most feed on leaves. This is the case for cycloalexic caterpillars, and larvae of sawflies [47], weevils, and leaf beetles [7, 40]. Some feed on fungal hyphae, such as Forcipomyia fuliginosa (Meigen, 1818) midge larvae [42], and the rest graze on lichen, like Anactinothrips gustaviae thrips [59].

Gregarious lifestyles, chemical defence, and grazing groups of immature insects are all traits of Costa's [24] "larval herd" syndrome of group living. Like cycloalexy, parental care is only present in some of these larval herds [24]. Possibly, the slow-moving and exposed lifestyle of these immature insects makes them more vulnerable to predators and parasitoids $[24,77]$. Increased threats probably explain the multiple defences of insect herbivores, including chemical defence whose evolution generally precedes that of aggregation [78].

\section{Conclusion}

Several immature insects exhibit cycloalexy, a behaviour whose definition we have amended to: "A preemptive defence employed at rest, where individuals form a circle with their best defended extremity exposed at the periphery. Sometimes remaining individuals rest at the centre of the circle."

In leaf beetles (Chrysomelidae), cycloalexy with abdomens oriented outwards is found in one genus of skeletonizing leaf beetles (Galerucinae: Coelomera spp.), at least fifteen tortoise beetle genera (Cassidinae), two genera of shining leaf beetles (Criocerinae: Lema and probably Lilioceris), and several genera of broad-shouldered leaf beetles (Chrysomelinae: Platyphora, probably Chrysophtharta and tentatively Eugonycha and Pterodunga). Cycloalexy with heads outwards is found in some sawflies (Tenthredinoidea: Pergidae: Perga spp. and Argidae: Themos olfersii (Klug, 1834)) of Australia and Brazil. Social caterpillars often form aggregations, but 
these aggregations are rarely cycloalexic. However, caterpillars of Lonomia spp. (Saturniidae: Hemileucinae) are probably cycloalexic and Papilio laglaizei Depuiset, 1877 (Papilionidae) are tentatively cycloalexic. One weevil Phelypera distigma (Boheman, 1842) (Curculionidae) is cycloalexic and one midge Forcipomyia fuliginosa (Ceratopogonidae) exhibits cycloalexy. We propose that some immature thrips are also probably cycloalexic and suggest formally changing the definition of cycloalexy to remove taxonomical restrictions so that any animals that meet all other criteria of the definition can be included. New instances of cycloalexy will undoubtedly be discovered. For example, Platydesmid millipedes sometimes aggregate in a tentatively analogous fashion.

Several reports of cycloalexy do not meet one or more of the revised definition criteria, including reports of cycloalexy in feeding aggregations of Hemiptera and larvae of Hymenopteran parasitoids. The behaviour has also been mistakenly attributed to adult Hymenoptera, for example, stingless bees (Apidae: Meliponinae), ants (Formicidae), and wasps (Vespidae), guarding their nest. This is active protection of a nest and not cycloalexy. Similarly, the term has been applied to the circular assembly of an amphipod crustacean which helps the mother herd the larvae. Owlfly larvae (Neuroptera: Ascalaphidae: Ascaloptynx furciger) form unidirectional defensive groups which are not cycloalexic, allowing larvae to feed without changing position. Defensive circles are sometimes observed in mammals: muskoxen, eland, water buffalo, red deer, and killer whales. Contrary to cycloalexy, the defensive formations in these mammals are a reaction to imminent threat. Other vertebrates, like penguins, huddle to reduce heat loss.

Application of a more precise definition of cycloalexy, as provided by Jolivet et al. [1] and revised here, may make unravelling the evolution of cycloalexic behaviour more tractable. Much remains to be learned about whether larval aggregation, cycloalexy, sequestration of plant metabolites, and maternal care are alternative defensive strategies or are honed evolutionary responses to particular threats. Chrysomeline leaf beetles are an ideal group for using phylogenetic reconstruction and character analysis of these behaviours to unravel the number of independent evolutionary origins of cycloalexy and larval aggregation.

\section{Conflict of Interests}

The authors declare that there is no conflict of interests regarding the publication of this paper.

\section{Acknowledgments}

This work was funded by the Natural Sciences and Engineering Research Council of Canada (NSERC), the Fonds de recherche du Québec Nature et technologies (FQRNT), McGill University, the Smithsonian Tropical Research Institute, and the Entomological Society of Quebec. The authors thank Dr. Laurence Mound (CSIRO) for identifying the thrips from Panama.

\section{References}

[1] P. Jolivet, J. Vasconcellos-Neto, and P. Weinstein, "Cycloalexy: a new concept in the larval defense of insects," Insecta Mundi, vol. 4, pp. 133-142, 1990.

[2] C. von Clausewitz and H. W. Gatzke, Principles of War, vol. 82, Military Service Publishing Company, Harrisburg, Pa, USA, 1942.

[3] J. Tener, A Preliminary Study of the Musk-Oxen of Fosheim Peninsula, Ellesmere Island, NWT, vol. 9 of Wildlife Management Bulletin, Canadian Wildlife Service, 1954.

[4] E. O. Wilson, Sociobiology: The New Synthesis, Belknap Press of Harvard University Press, Cambridge, Mass, USA, 1975.

[5] J. Vasconcellos-Neto and P. Jolivet, "Une nouvelle stratégie de défense: la stratégie de défense annulaire (cycloalexie) chez quelques larves de Chrysomélides brésiliens (Col.)ý," Bulletin de La Société Entomologique de France, vol. 92, no. 9-10, pp. 291299, 1988.

[6] J. Vasconcellos-Neto and P. Jolivet, "Ring defense strategy (cycloalexy) among Brazilian chrysomelid larvae (Coleoptera)," Entomography, vol. 67, pp. 347-354, 1989.

[7] J. Vasconcellos-Neto and P. Jolivet, "Cycloalexy among chrysomelid larvae," in Novel Aspects of the Biology of Chrysomelidae, P. Jolivet, M. L. Cox, and E. Petitpierre, Eds., pp. 303-309, Kluwer Academic Publishers, Dordrecht, The Netherlands, 1994.

[8] J. Vasconcellos-Neto and P. Jolivet, "Ring defense strategy among Brazilian Chrysomelid larvae (Col.)," in Proceedings of the 18th International Congress of Entomology, Vancouver, Canada, 1988.

[9] L. Medeiros, D. Ferro, and A. Mafra-Neto, "Association of Chrysomelid beetles with solanaceous plants in the south of Brazil," in Chrysomelidae Biology, P. Jolivet and M. L. Cox, Eds., pp. 339-363, SPC Academic Publishing, Amsterdam, The Netherlands, 1996.

[10] L. Medeiros, Aspectos da Interação Entre Especies de ChrysomeliNae (Coleoptera: Chrysomelidae) e Plantas da Familia Solanaceae Na Serra Do Japi, Jundiai, SP, Universidade Estadual de Campinas, Campinas, São Paulo, Brazil, 1991.

[11] J. A. Santiago-Blay, P. Jolivet, and K. K. Verma, "A natural history of conspecific aggregations in terrestrial arthropods, with emphasis on cycloalexy in leaf beetles (Coleoptera: Chrysomelidae)," Terrestrial Arthropod Reviews, vol. 5, no. 3-4, pp. 289-355, 2012.

[12] P. Jolivet and K. K. Verma, "Reflexions on cycloalexy among Chrysomelidae (Coleoptera)," Nouvelle Revue D'Entomologie, vol. 27, no. 4, pp. 311-329, 2011.

[13] C. Bontems and C.-F. Lee, "A new case of viviparity among Chrysomelinae," in Research on Chrysomelidae, P. Jolivet, J. A. Santiago-Blay, and M. Schmitt, Eds., pp. 260-264, Brill Academic Publishers, Leiden, The Netherlands, 2008.

[14] T. L. Simmul and D. W. de Little, "Biology of the paropsini (Chrysomelidae: Chrysomelinae)," in Advances in Chrysomelidae Biology 1, M. L. Cox, Ed., pp. 463-477, Backhuys Publishers, Leiden, The Netherlands, 1999.

[15] D. M. Windsor, G. J. Dury, F. A. Frieiro-Costa, S. Lanckowsky, and J. M. Pasteels, "Subsocial Neotropical Doryphorini 
(Chrysomelidae, Chrysomelinae): new observations on behavior, host plants and systematics," Research on Chrysomelidae, vol. 4, no. 332, pp. 71-93, 2013.

[16] S.-I. Kudô and E. Hasegawa, "Diversified reproductive strategies in Gonioctena (Chrysomelinae) leaf beetles," in New Contributions to the Biology of Chrysomelidae, P. Jolivet, J. A. SantiagoBlay, and M. Schmitt, Eds., pp. 727-738, SPB Academic Publishing, The Hague, The Netherlands, 2004.

[17] M. Daccordi, L. LeSage, and M. L. Cox, "Revision of the genus Labidomera Dejean with a description of two new species (Coleoptera: Chrysomelidae: Chrysomelinae)," in Advances in Chrysomelidae Biology 1, M. L. Cox, Ed., pp. 437-461, Backhuys Publishers, Leiden, The Netherlands, 1999.

[18] M. Daccordi, "Nuove specie di Platyphora della regione neotropicale (Coleoptera: Chrysomelidae, Chrysomelinae)," Memorie della Societá Entomologica Italiana, vol. 72, pp. 221232, 1993.

[19] C. A. M. Reid, M. Beatson, and J. Hasenpusch, "The morphology and biology of Pterodunga mirabile Daccordi, an unusual subsocial Chrysomeline (Coleoptera: Chrysomelidae)," Journal of Natural History, vol. 43, no. 7-8, pp. 373-398, 2009.

[20] B. J. Selman, "The biology of the paropsine eucalyptus beetles of Australia," in Novel Aspects of the Biology of Chrysomelidae, P. Jolivet, M. L. Cox, and E. Petitpierre, Eds., pp. 555-565, Kluwer Academic Publishers, Dordrecht, The Netherlands, 1994.

[21] P. Carne, "Ecological characteristics of the eucalypt-defoliating chrysomelid Paropsis atomaria Ol," Australian Journal of Zoology, vol. 14, no. 4, pp. 647-672, 1966.

[22] M. J. Wade, "The biology of the imported willow leaf beetle, Plagiodera versicolora (Laicharting)," in Novel Aspects of the Biology of Chrysomelidae, P. Jolivet, M. L. Cox, and E. Petitpierre, Eds., pp. 541-547, Kluwer Academic Publishers, Dordrecht, The Netherlands, 1994.

[23] M. J. Wade and F. Breden, "Life history of natural populations of the imported willow leaf beetle, Plagiodera versicolora (Coleoptera: Chrysomelidae)," Annals of the Entomological Society of America, vol. 79, no. 1, pp. 73-79, 1986.

[24] J. T. Costa, The Other Insect Societies, Belknap Press of Harvard University Press, Cambridge, Mass, USA, 2006.

[25] F. Breden and M. J. Wade, "An experimental study of the effect of group size on larval growth and survivorship in the imported willow leaf beetle, Plagiodera versicolora (Coleoptera: Chrysomelidae)," Environmental Entomology, vol. 16, pp. 10821086, 1987.

[26] M. S. Mohamedsaid, "A simple type of cycloalexy in larvae of Phyllocharis undulata (Linnaeus) (Chrysomelidae: Chrysomelinae)," Chrysomela, vol. 50-51, pp. 9-10, 2008.

[27] J. C. Choe, "Maternal care in Labidomera suturella Chevrolat (Coleoptera: Chrysomelidae: Chrysomelinae) from Costa Rica," Psyche, vol. 96, pp. 63-68, 1989.

[28] L. Medeiros and J. Vasconcellos-Neto, "Host plants and seasonal abundance patterns of some Brazilian Chrysomelidae," in Novel Aspects of the Biology of Chrysomelidae, pp. 184-189, Kluwer Academic Publishers, Dordrecht, The Netherlands, 1994.

[29] D. M. Windsor, "Natural history of a subsocial tortoise beetle, Acromis sparsa Boheman (Chrysomelidae, Cassidinae) in Panama," Psyche, vol. 94, no. 1-2, pp. 127-150, 1987.

[30] H. D. C. Heron, "Cycloalexy in two South African tortoise beetles (Chrysomelidae: Cassidinae)," Chrysomela, vol. 27, pp. 3-4, 1992.

[31] K. K. Verma, "Cycloalexy in the tortoise beetle, Aspidomorpha miliaris F. (Col. Chrys. Cass.)," Chrysomela, vol. 26, p. 6, 1992.
[32] J. Świętojańska, The Immatures of Tortoise Beetles With Bibliographic Catalogue of All Taxa (Coleoptera: Chrysomelidae: Cassidinae).", vol. 16 of Polish Taxonomical Monographs, Biologica Silesiae, Wrocław, Poland, 2009.

[33] H. D. C. Heron, "The biology of Conchyloctenia punctata (Fabricius). A cycloalexic cassid (Chrys. Cassidinae)," in Advances in Chrysomelidae Biology 1, M. L. Cox, Ed., pp. 565-580, Backhuys Publishers, Leiden, The Netherlands, 1999.

[34] C. S. Chaboo, "First report of immatures, genitalia and maternal care in Eugenysa columbiana (Boheman) (Coleoptera): Chrysomelidae: Cassidinae: Eugenysini)," Coleopterists Bulletin, vol. 56, no. 1, pp. 50-67, 2002.

[35] D. M. Windsor and J. C. Choe, "Origins of parental care in Chrysomelid beetles," in Novel Aspects of the Biology of Chrysomelidae, P. Jolivet, M. L. Cox, and E. Petitpierre, Eds., pp. 111-117, Kluwer Academic Publishers, Dordrecht, The Netherlands, 1994.

[36] J. Romero-Nápoles, "Morfología y biología de Ogdoecosta biannularis (Coleoptera: Chrysomelidae) en su huesped silvestre Ipomoea murucoides (Convolvulaceae) en al Estado de Morelos, Mexico," Folia Entomológica Mexicana, vol. 78, pp. 85-93, 1990.

[37] P. A. A. Gomes, F. Prezoto, and F. A. Frieiro-Costa, "Biology of Omaspides pallidipennis Boheman, 1854 (Coleoptera: Chrysomelidae: Cassidinae)," Psyche, vol. 2012, pp. 1-8, 2012.

[38] V. Rodriguez, "Sexual behavior in Omaspides convexicollis Spaeth and O. bistriata Boheman (Coleoptera: Chrysomelidae: Cassidinae), with notes on maternal care of eggs and young," The Coleopterists' Bulletin, vol. 48, no. 2, pp. 140-144, 1994.

[39] F. A. Frieiro-Costa, "Biologia de populações e etologia de Omaspides tricolorata (Boheman, 1854) (Coleoptera: Chrysomelidae: Cassidinae) na Serra do Japi-Jundiai-SP," in Instituto de Biologia, p. 175, Universidade Estadual de Campinas, Campinas, São Paulo, Brazil, 1995.

[40] P. Jolivet and J. -M. Maes, "Un cas de cycloalexie chez un Curculiondae: Phelypera distigma (Boheman) (Hyperinae) au Nicaragua,' L’Entomologiste, vol. 52, pp. 97-100, 1996.

[41] T. D. Fitzgerald, A. Pescador-Rubio, M. T. Turna, and J. T. Costa, "Trail marking and processionary behavior of the larvae of the weevil Phelypera distigma (Coleoptera: Curculionidae)," Journal of Insect Behavior, vol. 17, no. 5, pp. 627-646, 2004.

[42] A. M. Young, "Ecological notes on cacao associated midges (Dipt. Ceratopogonidae) in the "Catongo" cacao plantation at Turrialba," Proceedings of the Entomological Society of Washington, vol. 86, no. 1, pp. 185-194, 1984.

[43] L. G. Saunders, "On the life history and the anatomy of the early stages of Forcipomyia (Diptera, Nemat., Ceratopogoninae)," Parasitology, vol. 16, no. 02, pp. 164-213, 1924.

[44] H. E. Hinton, "Protective devices of Endopterygote pupae," Transactions of the Society For British Entomology, vol. 12, pp. 49-92, 1955.

[45] W. G. Eberhard, The Ecology and Behavior of a subsocial pentatomid Bug and Two Scelionid wasps: strategy and counterstrategy in a Host and Its parasites, vol. 205 of Smithsonian Contributions to Zoology, Smithsonian Institution Press, 1975.

[46] L. Filippi, M. Hironaka, and S. Nomakuchi, "A review of the ecological parameters and implications of subsociality in Parastrachia japonensis (Hemiptera: Cydnidae), a semelparous species that specializes on a poor resource," Population Ecology, vol. 43, no. 1, pp. 41-50, 2001.

[47] P. Weinstein, "Cycloalexy in an Australian pergid sawfly (Hymenoptera, Pergidae)," BullEtin et Annales de La Société Entomologique de Belgique, vol. 125, pp. 53-60, 1989. 
[48] P. B. Carne, "The characteristics and behaviour of the sawfly Perga affinis affinis (Hymenoptera)," Australian Journal of Zoology, vol. 10, no. 1, pp. 1-34, 1962.

[49] P. A. Morrow, T. E. Bellas, and T. Eisner, "Eucalyptus oils in the defensive oral discharge of Australian sawfly larvae (Hymenoptera: Pergidae)," Oecologia, vol. 24, no. 3, pp. 193-206, 1976.

[50] B. F. de Souza Dias, "Comportamento pré-social de Sínfitas do Brasil Central. I. Themos olfersii (Klug) (Hymenoptera, Argidae)," Studia Entomologica, vol. 18, no. 1-4, pp. 401-422, 1975.

[51] D. Wittmann, "Aerial defense of the nest by workers of the stingless bee Trigona (Tetragonisca) angustula (Latreille) (Hymenoptera: Apidae)," Behavioral Ecology and Sociobiology, vol. 16, no. 2, pp. 111-114, 1985.

[52] J. van der Vecht, "The social wasps (Vespidae) collected in French Guiana by the Mission du Muséum national d'Histoire naturelle, with notes on the genus Apoica Lepeletier," Annales de La Société Entomologique de France, vol. 8, pp. 735-743, 1972.

[53] K. M. Pickett, J. M. Carpenter, and A. Dejean, “"Basal” but not primitive: the nest of Apoica arborea de Saussure, 1854 (Insecta, Hymenoptera, Vespidae, Polistinae)," Zoosystema, vol. 31, no. 4, pp. 945-948, 2009.

[54] A. M. S. Neto and S. R. Andena, "New records of Apoica pallida (Olivier, 1792)(Hymenoptera: Vespidae, Epiponini) in Bahia State," EntomoBrasilis, vol. 4, no. 3, pp. 152-153, 2011.

[55] R. Straatman, "Notes on the biologies of Papilio laglaizei and $P$. toboroi (Papilionidae)," Journal of the Lepidopterists' Society, vol. 29, pp. 180-187, 1975.

[56] L. M. Lorini, P. H. G. Zarbin, and C. D. Tedesco, "Biology of laboratory-reared Lonomia Obliqua (Lepidoptera: Saturniidae)," Florida Entomologist, vol. 90, no. 4, pp. 770-771, 2007.

[57] M. da Saúde, "V-Acidentes por Lepidópteros," in Manual de Diagnóstico d Tratamdnto de Acidentes Por Animais Peçonhentos, pp. 75-84, Fundação Nacional de Saúde, Brasília, Brazil, 1998.

[58] C. S. Henry, "Eggs and rapagula of Ululodes and Ascaloptynx (Neuroptera: Ascalaphidae): a comparative study," Psyche, vol. 79, no. 12, pp. 1-22, 1972.

[59] A. R. Kiester and E. Strates, "Social behaviour in a thrips from Panama," Journal of Natural History, vol. 18, no. 2, pp. 303-314, 1984.

[60] P. Laval, "The barrel of the pelagic amphipod Phronima sedentaria (Forsk.) (Crustacea: hyperiidea)," Journal of Experimental Marine Biology and Ecology, vol. 33, no. 3, pp. 187-211, 1978.

[61] P. Laval, "Hyperiid amphipods as crustacean parasitoids associated with gelatinous zooplankton," Oceanography and Marine Biology: Annual Review, vol. 18, pp. 11-56, 1980.

[62] G. Hoffmann, "Diplopoda," in Synopsis and Classification of Living Organisms, S. P. Parker, Ed., vol. 2, pp. 689-724, McGrawHill, New York, NY, USA, 1982.

[63] C. Gilbert, G. Robertson, Y. Le Maho, Y. Naito, and A. Ancel, "Huddling behavior in emperor penguins: dynamics of huddling," Physiology and Behavior, vol. 88, no. 4-5, pp. 479-488, 2006.

[64] P. Jolivet, "Cycloalexy," in Encyclopedia of Entomology, J. L. Capinera, Ed., pp. 1139-1140, Springer, New York, NY, USA, 2008.

[65] J. T. Costa, T. D. Fitzgerald, A. Pescador-Rubio, J. Mays, and D. H. Janzen, "Social behavior of larvae of the neotropical processionary weevil Phelypera distigma (Boheman) (Coleoptera:
Curculionidae: Hyperinae)," Ethology, vol. 110, no. 7, pp. 515530, 2004.

[66] H. Kruuk, The Spotted Hyena: A Study of predation and social behavior, University of Chicago Press, Chicago, IL, USA, 1972.

[67] J. F. Eisenberg and M. Lockhart, "An ecological reconnaissance of Wilpattu National Park, Ceylon," Smithsonian Contributions to Zoology, vol. 101, pp. 1-118, 1972.

[68] F. F. Darling, A Herd of Red Deer, Oxford University Press, London, UK, 1937.

[69] D. R. Martinez and E. Klinghammer, "The behavior of the whale Orcinus orca: a review of the literature," Zeitschrift Für Tierpsychologie, vol. 27, no. 7, pp. 828-839, 1970.

[70] M. Altmann, "Patterns of herd behavior in freeranging elk of Wyoming, Cervus canadensis nelsoni," Zoologica, vol. 41, pp. 65-71, 1956.

[71] W. D. Hamilton, "Geometry for the selfish herd," Journal of Theoretical Biology, vol. 31, no. 2, pp. 295-311, 1971.

[72] L. Mound and J. Palmer, "Spore-feeding Thysanoptera of the genus Anactinothrips with a new sub-social species from Panama," Journal of Natural History, vol. 17, no. 5, pp. 789-797, 1983.

[73] A. B. G. Veiga, B. Blochtein, and J. A. Guimarães, "Structures involved in production, secretion and injection of the venom produced by the caterpillar Lonomia obliqua (Lepidoptera, Saturniidae)," Toxicon, vol. 39, no. 9, pp. 1343-1351, 2001.

[74] N. E. Gómez, L. Witte, and T. Hartmann, "Chemical defense in larval tortoise beetles: essential oil composition of fecal shields of Eurypedus nigrosignata and foliage of its host plant, Cordia curassavica," Journal of Chemical Ecology, vol. 25, no. 5, pp. 1007-1027, 1999.

[75] K. L. Olmstead and R. F. Denno, "Effectiveness of tortoise beetle larval shields against different predator species," Ecology, vol. 74, no. 5, pp. 1394-1405, 1993.

[76] F. V. Vencl, T. C. Morton, R. O. Mumma, and J. C. Schultz, "Shield defense of a larval tortoise beetle," Journal of Chemical Ecology, vol. 25, no. 3, pp. 549-566, 1999.

[77] H. V. Cornell and B. A. Hawkins, "Survival patterns and mortality sources of herbivorous insects: some demographic trends," The American Naturalist, vol. 145, no. 4, pp. 563-593, 1995.

[78] G. D. Ruxton and T. N. Sherratt, "Aggregation, defence and warning signals: the evolutionary relationship," Proceedings of the Royal Society B, vol. 273, no. 1600, pp. 2417-2424, 2006. 

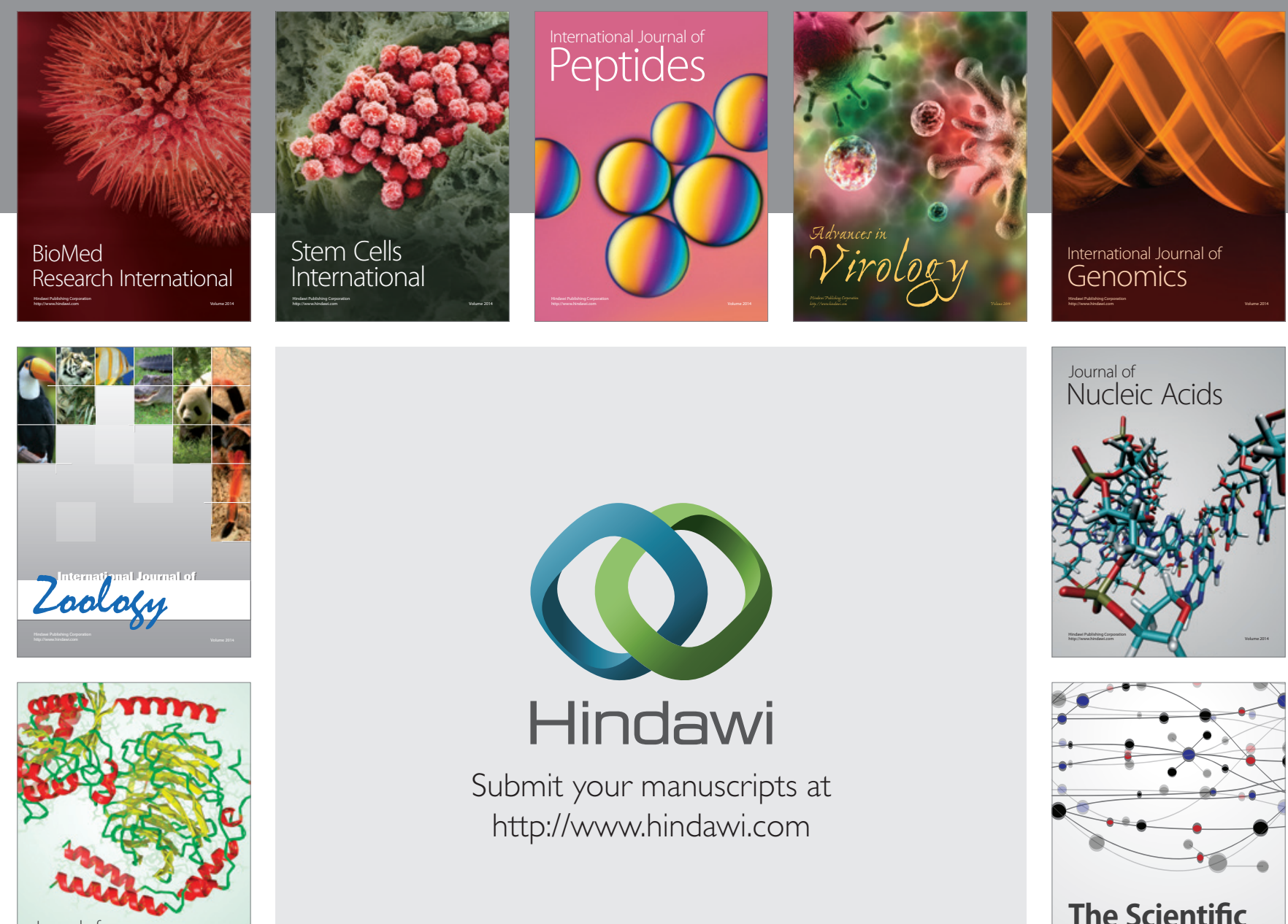

Submit your manuscripts at

http://www.hindawi.com

Journal of
Signal Transduction
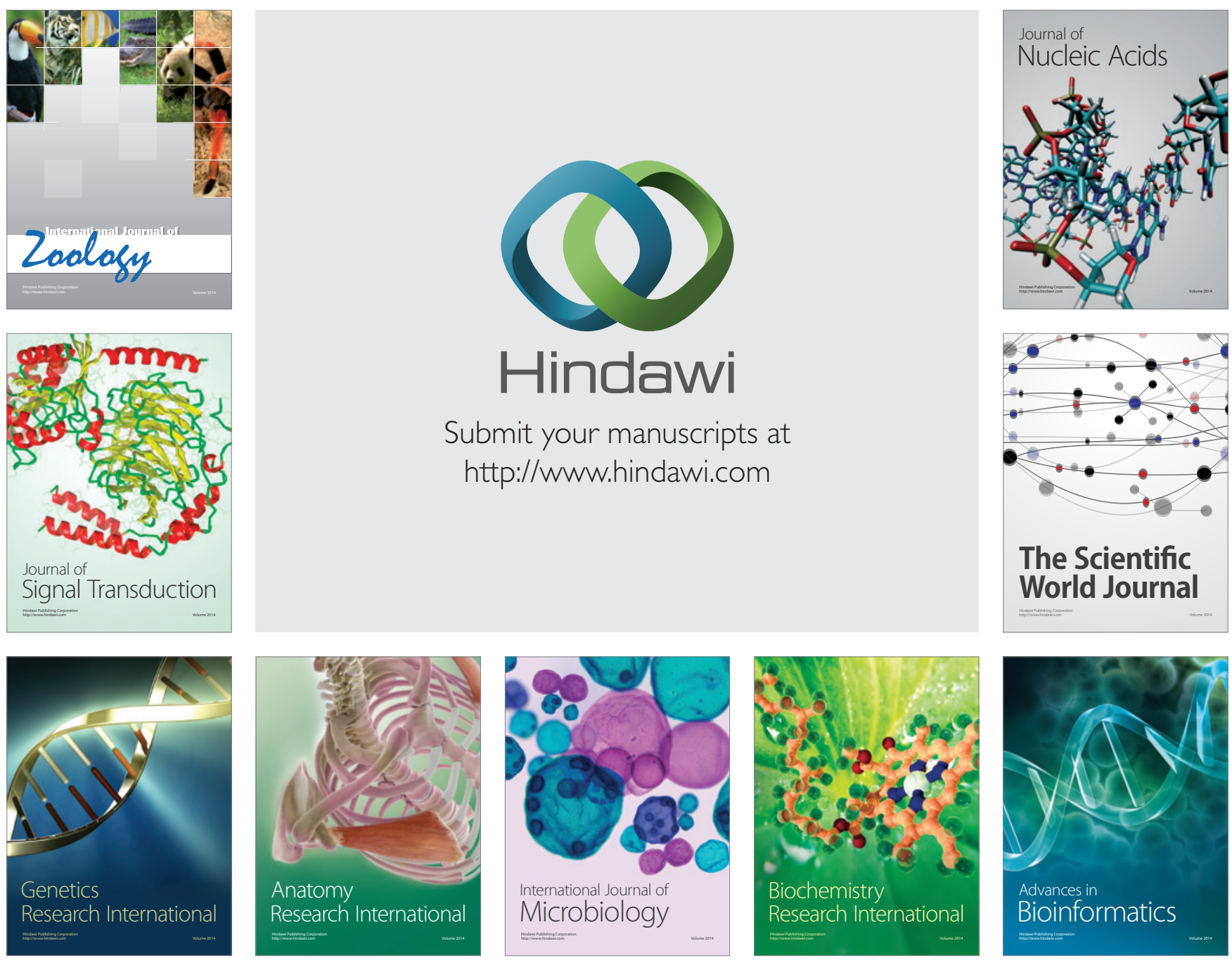

The Scientific World Journal
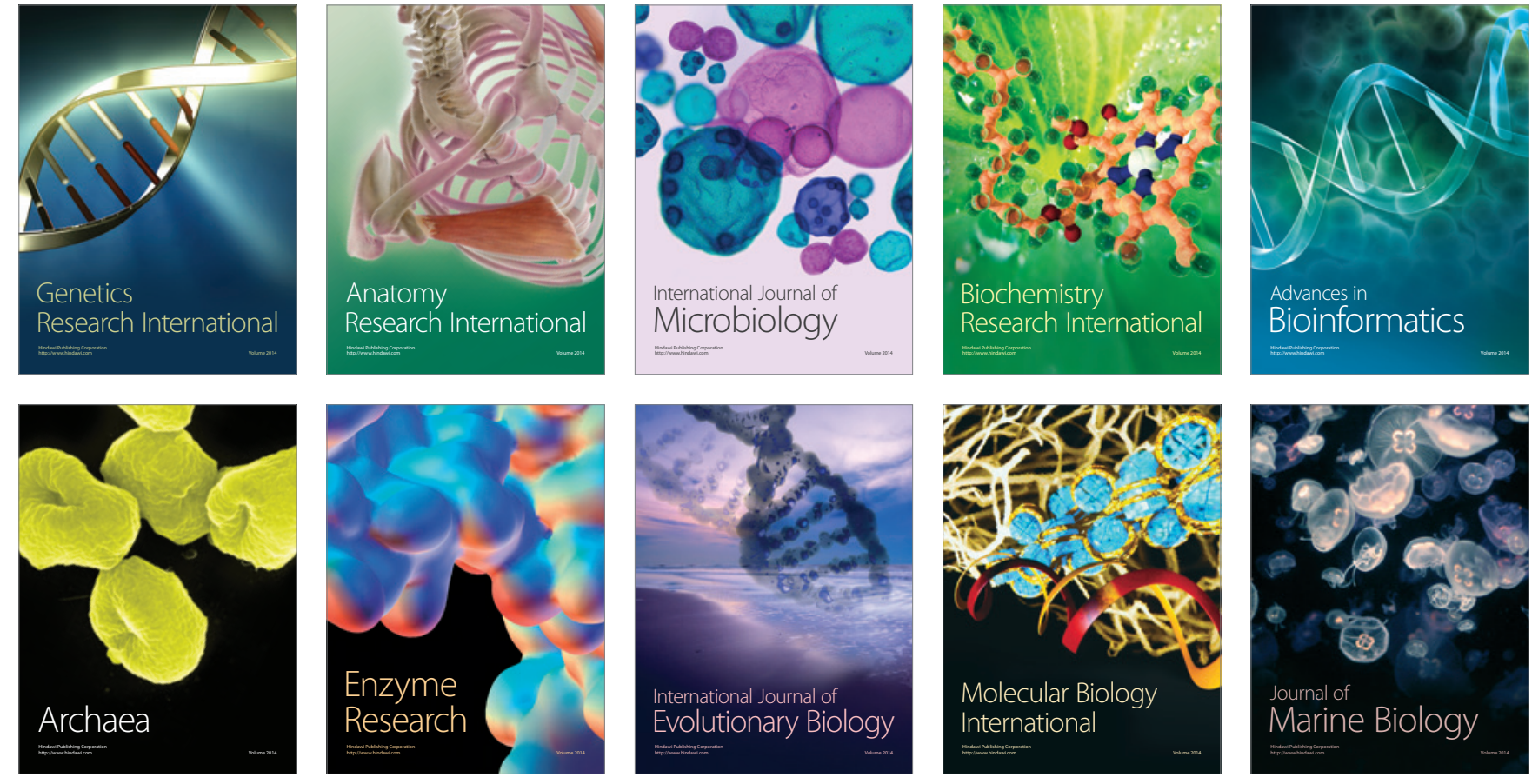